\title{
EFFECT OF GROWING MEDIA, ORGANIC FERTILIZATION AND BIOSTIMULANTS ON THE PRODUCTION OF GLADIOLUS (CV. NOVALUX) CORMS FROM CORMLETS
}

\author{
Reem M. Saeed"; W.M. Bazaraa ${ }^{* *}$ and A. Nabih ${ }^{*}$ \\ * Botanical Gardens Res. Dept., Hort. Res. Inst., ARC., Giza, Egypt. \\ ** Ornamental Plants and Landscape Gardening Res. Dept., Hort. Res. Inst., ARC., Giza, Egypt.
}

ABSTRACT: In a trial to solve one of the most important problems faced the production of Gladiolus plant in Egypt, i. e. the deterioration of corms production year after year. Therefore, they are annually imported from Netherlands. But in view of the rising prices of corms in recent years, studying the factors that may help to produce the corms locally is very necessary. So, the experimental trial was performed during two successive seasons (2011/2012 and 2012/2013) at the nursery of Horticulture Research Institute, Giza, Egypt. It intended to investigate the independent as well as the combined effects of different growing media (sand, sand/compost $(1: 1 \mathrm{v} / \mathrm{v})$; sand/sewage sludge $(3: 1 \mathrm{v} / \mathrm{v})$ and organic

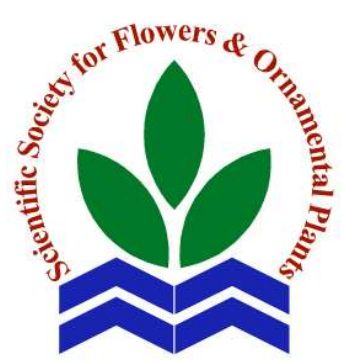

Scientific J. Flowers \& Ornamental Plants, 1(1):73-87 (2014).

Received:

$4 / 2 / 2014$

Revised by: Prof. Dr. A.Z. Sarhan, Cairo Univ.

Prof. Dr. Naglaa Y.L. Eliwa, Hort. Res. Inst., ARC. fertilization (actosol) and biostimulants (garlic and yeast extracts) on the production of Gladiolus corms from cormlets (cv. Novalux) locally.

The results indicated that sand/compost $(1: 1 \mathrm{v} / \mathrm{v})$ medium proved its mastery for increasing corms yield (No. of corms/experimental unit), corm fresh and dry weights, corm circumference, root length of the new formed corms, cormlets yield and cormlet fresh and dry weights. Using sand medium in plantation occupied the second rank in improving such parameters in both seasons. Meanwhile, slight effects were obtained on the same parameters due to using sand/sewage sludge medium in plantation. Chemical constituents of the new formed corms indicated also the prevalence of using sand/compost medium in raising N, P, K and total carbohydrates \%. Actosol treatment proved its superiority in increasing both corms yield and quality in both seasons. Meanwhile, applying garlic extract occupied the second rank in improving the same traits with significant effect comparing with control in most cases. However, using yeast extract slightly improved these parameters and achieved the third position. Results, also showed the prevalence of treating plants with actosol for increasing cormlets yield (No. of cormlets/experimental unit) whereas, garlic extract achieved the second position for elevating the same parameter. Meanwhile, yeast application recorded the least effect in improving such trait. In the same time, either organic fertilization (actosol) or biostimulants (garlic and yeast) slightly improved cormlet fresh and dry weights, with insignificant effect in most cases. Also, the previous treatments showed slight increments on $\mathrm{N}, \mathrm{P}, \mathrm{K}$ and total carbohydrates \% in new formed corms, where actosol was the best in this respect.

Form the aforementioned results and interactions it could be recommended to grow Gladiolus (cv. Novalux) cormlets in sand/compost $(1: 1 \mathrm{v} / \mathrm{v})$ medium and treating plants with organic fertilization (actosol) for producing the best corms and cormlets yield and quality.

Key words: Gladiolus (cv. Novalux), growing media, organic fertilization (actosol), biostimulants (garlic and yeast extracts). 


\section{Reem M. Saeed et al.}

\section{INTRODUCTION}

Gladiolus is one of the best and most important flowering bulbs. It belongs to the family Iridaceae (Bailey, 1971). The flowers are exported to European and American markets the year around, especially in winter and early spring. The most important problem faced the production of gladiolus in A.R.E. is the deterioration of corms production year after year. Therefore, they are annually imported from Netherlands. But in view of the rising prices of corms in recent years studying the factors that may help to produce the corms locally is very necessary. Growing media, organic fertilization and biostimulants (such as garlic and yeast extracts) may be of the important factors affecting the production of gladiolus corms from cormlets. However, very little work was carried out regarding the effects of the previous factors on the production of gladiolus corms. So, the literature on other corms or bulbs is indispensable in this concern.

Referring the effects of growing media, it is well known that soil fertility means the soil capacity to supply the plants with their requirements from nutrients, water and air along the growth season (Askar, 1988). Sandy soil has poor hydrophysical properties. Soil conditioners are widely utilized to compensate the limited supply of nutrients as well as increase water use efficiency (John and David, 2000). Amending the organic compost into the sandy soil proved highly beneficial effect on both soil properties and plant growth. Decomposition of the compost allows more releasing of inorganic elements in available forms to be more easily taken by the plant roots. Sewage sludge proved highly beneficial effects on sand and calcareous soils and has been described as the most suitable organic conditioners for the desert soil (Askar, 1988). Nasr (2000) on tuberose plant concluded that sand/composted leaves followed by sand/clay media resulted in significant increase in bulbs yield and fresh and dry weights of produced bulblets.
Abbass (2003) on Polianthes tuberosa, found that adding the sewage sludge at the high level (15\%) increased leaves dry weight, number of bulbs as well as leaf content of N, P and K. Nady and Hassanein (2004) on Dahlia pinnata, mentioned that poultry manure at the high rate $\left(8 \mathrm{~m}^{3} / \mathrm{fed}\right)$ surpassed other organic treatments in augmenting roots production and chemical constituents. Abdel-Sattar et al. (2010) on Polianthes tuberosa stated that planting in sand + compost mixture $(3: 1 \mathrm{v} / \mathrm{v})$ produced higher quality and quantity of bulbs and bulblets, whereas, planting in sand/sewage sludge $(3: 1 \mathrm{v} / \mathrm{v})$ mixture led to increase the content of $\mathrm{N}, \mathrm{P}, \mathrm{K}$, amino acids, total, reduced and non- reduced sugars in the new formed bulbs. El-Sayed et al. (2012) on Fressia refracta $\mathrm{cv}$. Red Lion concluded that growing cormlets in sand/sewage sludge medium $(3: 1 \mathrm{v} / \mathrm{v})$ gave rise to some extent corms yield, fresh weight of new corms, corms circumference and fresh weight of cormlets, besides it increased $\mathrm{N}$ and $\mathrm{P} \%$ in new corms.

Actosol is an organic fertilizer containing 2.9\% humic acid and either $\mathrm{Fe}$, Zn or Mn (El-Seginy, 2006). Using actosol containing humic acid seems to be valuable in correcting the widespread occurrence of certain nutrient efficiency symptoms. It also acts as a source of nitrogen, phosphorus and sulfur for plants (Petrovic et al., 1982 and Higa and Widdana, 1991). Additionally, the presence of humic substances (HS) improves water- holding capacity, $\mathrm{pH}$ buffering and thermal insulation (Stevenson, 1994). Referring the beneficial effect of actosol in improving bulbs productivity. Sangeetha et al. (2008), on onion mentioned that soil application of humic as $20 \mathrm{~kg} /$ ha with $100 \%$ of the recommended dose of NPK fertilizers $(60: 60: 30 \mathrm{~kg} / \mathrm{ha})$ recorded the highest number of bulbs/plant and bulbs weight and yield. Eliwa et al. (2009) on Iris tingitana cv. Wedgewood, concluded that bulbs yield revealed an increment in response to actosol treatment at 10 or $20 \mathrm{ml} / \mathrm{l}$ as soil drench. Similarly, bulbs fresh weight was also increased due to actosol treatment at the rate 
of $2.5 \mathrm{ml} / 1$ as a foliar spray El-Sayed et al. (2010), on two gladiolus cvs. (White and Rose prosperity), concluded that soaking the corms before planting in actosol solution at the rate of $20 \mathrm{ml} / 1$ for 0,12 and 24 hours increased new corm diameter and its fresh and dry weights as well as number of cormlets/plant in both cultivars with prolonging soaking period in actosol solution. Atowa (2012) on Freesia refracta cv. Red Lion stated that beneficial effects were recorded due to applying actosol at 2.5 $\mathrm{ml} / 1$ on corms and cormels productivity produced from cormlets. Also, it was the best for elevating total carbohydrates in leaves and $\mathrm{P} \%$ in new corms.

On the other side, the effect of juices or extracts of certain plants as biostimulants (sometimes referred to as botanical activators or botanicals) was tried successfully by many workers. The active dry yeast (baker's dry yeast) Saccharomyces cervisiae proved high beneficial effect on plant nutrition (Skoog and Mitler, 1957), it contains cytokinins which effectively promot plant growth and delay leaf aging. The positive effects of applying yeast to plant can be attributed to its high nutrient contents, high protein, large amount of vitamin B and natural plant growth regulators such as cytokinins (Ahmed, 2002). Abbass (2008) on Narcissus tazetta found that using the yeast solution led to significant increase in $\mathrm{N}$ and P content in leaf and bulb. Emam (2010) on Polianthes tuberosa, concluded that highest records in fresh weight of bulb was the outcome of applying yeast treatment at 3, 5, 7 and $9 \mathrm{ml} / \mathrm{l}$. Atowa (2012) on Freesia refracta $\mathrm{cv}$. Red Lion stated that using yeast extract at $2.5 \mathrm{~g} / 1$ was the best for improving corms and cormlets productivity and increased $\mathrm{N}, \mathrm{P}$ and $\mathrm{K}$ contents in leaves. Meanwhile, $\mathrm{N}$ and $\mathrm{P} \%$ content in the new formed corms was increased as a result of using the same yeast level $(2.5 \mathrm{~g} / \mathrm{l})$.

Concerning the beneficial effect of garlic extract on bulbs productivity. Gomma et al. (2005), found that garlic extract level $(25,50$ and $100 \%$ ) as a foliar spray significantly increased bulbs and bulblets of Narcissus tazetta cv. Geranium plants. Emam (2010) on Polianthes tuberosa, concluded that garlic extract at the lowest level $(1 \mathrm{ml} / \mathrm{l})$ increased clump fresh weight, whereas at $5 \mathrm{ml} / 1$ raised clump dry weight, number of bulbs/plant (bulbs yield) and number of bulblets/plant (bulblets yield). Atowa (2012) on Freesia refracta $\mathrm{cv}$. Red Lion concluded that using garlic extract at $250 \mathrm{ml} / 1$ was the best for raising total carbohydrates content in leaves. Meanwhile, $\mathrm{K} \%$ content in the new corms was increased as a result of using garlic extract at either 250 or $500 \mathrm{ml} / 1$.

Therefore, the present experiment was consummated to find out the effect of growing media, organic fertilization (Actosol) and some biostimulants (garlic and yeast extracts) on the production of gladiolus corms from cormlets (cv. Novalux).

\section{MATERIALS AND METHODS}

The experimental trial was performed throughout two successive seasons (2011/2012 and 2012/2013) at the nursery of Horticulture Research Institute, Giza, Egypt. It was performed to cover the independent and combined effects of different growing media s sand, sand/compost $(1: 1 \mathrm{v} / \mathrm{v})$ and sand/sewage sludge $(3: 1 \mathrm{v} / \mathrm{v})\}$, organic fertilization (actosol) and biostimulants (garlic and yeast extracts) on the production of corms for cormlets of Gladiolus cv. Novalux.

\section{Plant materials:}

- Locally produced cormlets of 0.7-0.8 cm in diameter were selected and stored at $5^{\circ} \mathrm{C}$ pre-planting for three months to study the effect of different growing media, organic fertilization and biostimulants on the production of corms from cormlets of Gladiolus cv. Novalux in the two seasons.

- Different growing media of sand, sand/compost $(1: 1 \mathrm{v} / \mathrm{v})$ and sand/sewage sludge $(3: 1 \mathrm{v} / \mathrm{v})$ were used in the two seasons. Physical and chemical properties of sand, compost and sewage sludge are presented in Tables (a, b and c, respectively). 
Table a. Physical and chemical properties of sand used in plantation.

\begin{tabular}{|c|c|c|c|c|c|c|c|c|c|c|c|c|c|c|}
\hline \multirow{2}{*}{$\begin{array}{c}\text { Soil } \\
\text { Medium }\end{array}$} & \multicolumn{4}{|c|}{ Particle size distribution \% } & \multirow[b]{2}{*}{ S.P } & \multirow[b]{2}{*}{ pH } & \multirow[b]{2}{*}{$\begin{array}{c}\text { E.C. } \\
\text { Dsm }^{-1}\end{array}$} & \multicolumn{4}{|c|}{ Cations (meq/l) } & \multicolumn{3}{|c|}{ Anions (meq/l) } \\
\hline & $\begin{array}{l}\text { Coarse } \\
\text { Sand } \\
\end{array}$ & $\begin{array}{l}\text { Fine } \\
\text { Sand } \\
\end{array}$ & Clay & Silt & & & & $\mathrm{Ca}^{++}$ & $\mathbf{M g}^{++}$ & $\mathbf{N a}^{+}$ & $\mathbf{K}^{+}$ & $\mathrm{HCO}_{3}^{-}$ & $\mathrm{Cl}^{-}$ & $\mathrm{SO}_{4}^{-}$ \\
\hline Sand & 88.04 & 3.21 & 0.72 & 8.03 & 21.07 & 7.75 & 3.46 & 13.46 & 4.98 & 20.40 & 0.62 & 2.40 & 14.50 & 22.56 \\
\hline
\end{tabular}

Table b. Chemical properties of the used compost.

\begin{tabular}{|c|c|c|c|c|c|c|c|c|c|c|c|c|c|c|}
\hline \multirow{2}{*}{$\begin{array}{l}\text { Organic } \\
\text { additive } \\
\text { type }\end{array}$} & \multicolumn{5}{|c|}{ Macro elements \% } & \multicolumn{4}{|c|}{ Micro elements (ppm) } & \multirow{2}{*}{$\begin{array}{c}\text { O.C. } \\
\%\end{array}$} & \multirow{2}{*}{$\begin{array}{c}\text { O.M } \\
\%\end{array}$} & \multirow{2}{*}{$\begin{array}{c}\mathrm{C} / \mathrm{N} \\
\text { Ratio }\end{array}$} & \multirow{2}{*}{$\mathbf{p H}$} & \multirow{2}{*}{$\begin{array}{l}\text { E.C. } \\
\text { dSm }^{1}\end{array}$} \\
\hline & $\mathbf{N}$ & $\mathbf{P}$ & $\mathbf{K}$ & $\mathbf{C a}$ & Mg & $\mathbf{Z n}$ & $\mathbf{F e}$ & Mn & $\mathrm{Cu}$ & & & & & \\
\hline Compost & 1.41 & 0.47 & 1.82 & 0.17 & 0.74 & 28.46 & 10.21 & 110 & 46 & 12.54 & 21.56 & 8.90 & 8.11 & 4.10 \\
\hline
\end{tabular}

Table c. The main characteristics of the used sewage sludge.

\begin{tabular}{|c|c|c|c|c|}
\hline \multirow{2}{*}{ Property factors } & \multicolumn{4}{|c|}{ Macro element values } \\
\hline & $\mathbf{P}$ & $\mathbf{K}$ & Mg & $\mathbf{C a}$ \\
\hline Soluble macronutrients $\left(\mathrm{mg} \cdot \mathrm{kg}^{-1}\right)$ & 7.40 & 40 & 39 & 360 \\
\hline \multirow[t]{3}{*}{ Total macronutrients (mg.kg $\left.{ }^{-1}\right)$} & 3150 & 2585 & 8367 & 44000 \\
\hline & \multicolumn{4}{|c|}{ Micro element values } \\
\hline & $\mathbf{F e}$ & Mn & Zn & $\mathbf{C u}$ \\
\hline Extractable micronutrients (mg.kg-1 by DPTPA at pH7.3) & 455 & 59 & 604 & 38 \\
\hline \multirow[t]{3}{*}{ Total micronutrients (mg. kg $\left.{ }^{-1}\right)$} & 23031 & 413 & 2159 & 1035 \\
\hline & \multicolumn{4}{|c|}{ Heavy metal values } \\
\hline & $\mathbf{P b}$ & $\mathbf{N i}$ & Cd & Co \\
\hline Extractable heavy metals (mg.kg-1 by DPTPA at pH7.3) & 25 & 30 & 2.10 & 1.40 \\
\hline \multirow[t]{2}{*}{ Total heavy metals $\left(\mathrm{mg} \mathrm{kg}^{-1}\right)$} & 638.0 & 119.50 & 30.40 & 34.20 \\
\hline & \multicolumn{4}{|c|}{ Chemical Properties values } \\
\hline EC(1:20 extraction $) \mathrm{dsm}^{-1}$ & \multicolumn{4}{|c|}{2.10} \\
\hline pH(1:10 suspension) & \multicolumn{4}{|c|}{7.10} \\
\hline Organic matter \% & \multicolumn{4}{|c|}{49.30} \\
\hline Total nitrogen \% & \multicolumn{4}{|c|}{2.50} \\
\hline Moisture content & \multicolumn{4}{|c|}{7.00} \\
\hline Bulk density $\left(\mathrm{g} \mathrm{cm}^{-3}\right)$ & \multicolumn{4}{|c|}{0.51} \\
\hline
\end{tabular}

-Actosol: Is a commercial liquid organic fertilizer containing 2.9\% humic acid and either of $\mathrm{Fe}, \mathrm{Zn}$ or $\mathrm{Mn}$. The main charactereristics of the used liquid active fertilizer (Actosol) is presented in Table (d).

\section{-Natural extracts were prepared as follows:}

a-Garlic (Allium sativum): $50 \mathrm{~g}$ of meshed garlic cloves were soaked in $20 \mathrm{ml}$ ethyl alcohol (95\%) and $80 \mathrm{ml}$ of water for 24 hours before fiteration and adjusted to 1 liter (as a stock).
b-Yeast (Saccharomyces cerevisiae): $2.5 \mathrm{~g}$ dry yeast plus $1 \mathrm{ml}$ molasses $+2 \mathrm{ml}$ water were mixed in a warm place $(24 \mathrm{~h})$ and adjusted with water to 1 liter.

The main constituents of garlic bulbs, garlic oil and active dry yeast are presented in Table (e, $\mathrm{f}, \mathrm{g})$.

\section{Procedure:}

The cormlets were planted on October $26^{\text {th }}$ in $20 \mathrm{~cm}$ diameter of plastic pots (4 cormlets/plot) filled with about $2.5 \mathrm{~kg} / \mathrm{pot}$ of the above mentioned growing media used (sand, sand/compost $(1: 1 \quad \mathrm{v} / \mathrm{v})$ and sand/sewage sludge $(3: 1 \mathrm{v} / \mathrm{v})$. The pots of 
every type of growing media were redivided again into four groups for studying the effect of organic fertilization (actosol) and biostimulants treatments (garlic and yeast extracts), besides untreated plants (control). Thus, 12 treatments were carried out in the two seasons.

Table d. Main characteristics of the used liquid active fertilizer (actosol) according to El-Seginy (2006).

\begin{tabular}{llllll}
\hline Components & Value & Components & Value & Components & Value \\
Humic acid (\%) & 2.9 & $\mathbf{E c}\left(\mathbf{d s ~ m}^{-1}\right)$ & 5.90 & $\mathbf{B}(\mathbf{m g} / \mathbf{l})$ & 70.00 \\
Organic matter/total solids \% & 42.51 & $\mathbf{N \%}$ & 10.00 & $\mathbf{F e}(\mathbf{m g} / \mathbf{l})$ & 900.00 \\
Total HA/total solids\% & 168.80 & $\mathbf{P \%}$ & 10.00 & $\mathbf{M n}(\mathbf{m g} / \mathbf{l})$ & 90.00 \\
Organic carbon (\%) & 24.64 & $\mathbf{K \%}$ & 10.00 & $\mathbf{Z n}(\mathbf{m g} / \mathbf{l})$ & 90.00 \\
C/N ratio & 2.46 & $\mathbf{C a} \%$ & 0.06 & & \\
$\mathbf{p H}$ & 8.10 & $\mathbf{M g} \%$ & 0.05 & & \\
\hline
\end{tabular}

Table e. The main constituents of garlic bulbs, Duke, James (1992).

\begin{tabular}{lcccccc}
\hline Arginine & Ascorbic acid Aspartic acid & $\begin{array}{c}\text { Beta } \\
\text { carotene }\end{array}$ & Biotin & Caffeic acid & Carbohydrates \\
\hline $6.340 \mathrm{ppm}$ & $100.0 \mathrm{ppm}$ & $4.890 \mathrm{ppm}$ & $0.17 \mathrm{ppm}$ & $6.0 \mathrm{ppm}$ & $2.0 \mathrm{ppm}$ & $274.0 \mathrm{ppm}$ \\
\hline
\end{tabular}

Table f. The main constituents of garlic bulbs oil (Abou Hadid et al., 1998).

\begin{tabular}{|c|c|c|c|c|c|}
\hline Constituents & $\%$ & Constituents & $\%$ & Constituents & $\%$ \\
\hline Methyl allyl sulfide & 4.70 & Diallyl sulfide & 26.8 & Dimethyl trisulfide & 0.27 \\
\hline Allyl sulfide & 2.30 & Diallyl trisufide & 4.43 & Diallyl-disulfide & 49 \\
\hline Di-n-propyl sulfide & 0.70 & Di-n-Butyl sulfide & 8.06 & Hixanol & 0.12 \\
\hline $\begin{array}{l}\text { Tert. Butyl } \\
\text { Mercaptime }\end{array}$ & Trace & $\begin{array}{l}\text { Methyl propenyl } \\
\text { Disulfide }\end{array}$ & 0.04 & Methyl allyl trisulfide & 0.11 \\
\hline $\begin{array}{l}\text { Unidentified } \\
\text { Compounds }\end{array}$ & 3.50 & & & & \\
\hline
\end{tabular}

Table g. Chemical composition of active dry yeast (mg/g).

\begin{tabular}{llll}
\hline & \multicolumn{3}{c}{ Content of Chemicals } \\
\hline Proteins & $47 \%$ & Niacin & $300-500 \mathrm{mg} / \mathrm{g}$ \\
Carbohydrate & $33 \%$ & Pyridoxine & $28.0 \mathrm{mg} / \mathrm{g}$ \\
Minerals & $8.0 \%$ & Pantothenate & $70.0 \mathrm{mg} / \mathrm{g}$ \\
Nucleic acids & $8.0 \%$ & Biotin & $1.3 \mathrm{mg} / \mathrm{g}$ \\
Lipids & $4.0 \%$ & Choline & $40.0 \mathrm{mg} / \mathrm{g}$ \\
Thiamine & $60-100 \mathrm{mg} / \mathrm{g}$ & Folic acid & $5.13 \mathrm{mg} / \mathrm{g}$ \\
Riboflavin & $35-50 \mathrm{~m} / \mathrm{g}$. & Vitamin B2 & $0.001 \mathrm{mg} / \mathrm{g}$ \\
\hline & & Content $\mathbf{~ o f ~ M i n e r a l s ~}$ & \\
\hline Na & $\mathbf{C u}$ & $8.0 \mathrm{mg} / \mathrm{g}$ \\
Ca & $0.12 \mathrm{mg} / \mathrm{g}$ & Se & $0.1 \mathrm{mg} / \mathrm{g}$ \\
Fe & $0.75 \mathrm{mg} / \mathrm{g}$ & $\mathbf{M n}$ & $0.2 \mathrm{mg} / \mathrm{g}$ \\
Mg & $0.02 \mathrm{mg} / \mathrm{g}$ & $\mathbf{C r}$ & $2.2 \mathrm{mg} / \mathrm{g}$ \\
$\mathbf{K}$ & $1.65 \mathrm{mg} / \mathrm{g}$ & $\mathbf{N i}$ & $3.0 \mathrm{mg} / \mathrm{g}$ \\
$\mathbf{P}$ & $21.0 \mathrm{mg} / \mathrm{g}$ & $\mathbf{V a}$ & $0.04 \mathrm{mg} / \mathrm{g}$ \\
$\mathbf{Z n}$ & $13.50 \mathrm{mg} / \mathrm{g}$ & Sin & $3.0 \mathrm{mg} / \mathrm{g}$ \\
Si & $0.17 \mathrm{mg} / \mathrm{g}$ & Li & $0.17 \mathrm{mg} / \mathrm{g}$ \\
\hline
\end{tabular}




\section{Experiment Design:}

The layout of the experiment in the two seasons was a factorial experiment in randomized complete block design (RCBD) with three replicates. Every treatment contained $\quad 36 \quad$ cormlets $\quad$ (12 cormlets/experimentl unite). The first factor was the type of growing media, whereas, the second one was organic fertilization (actosol) and biostimulants treatments.

Actosol, garlic and yeast extracts were applied as a soil drench $(2.5 \mathrm{ml} / 1,250 \mathrm{ml} / 1$ and $2.5 \mathrm{~g} / 1$, respectively) 8 times at 15 days intervals commencing from January $15^{\text {th }}$ to May $15^{\text {th }}$, besides untreated control plants. Every pot received $100 \mathrm{ml}$ of the prepared solutions. The plants left to grow at open field condition till drying the leaves (i. e. complete formation of new corms and cormlets).

Regular agricultural practices such as weeding, watering... etc were carried out whenever necessary. Every pot received 15\% of its volume fresh water in every irrigation.

\section{Data were registered as follows:}

- Number of corms/experimental unite (corms yield).

- Corm fresh weight (g).

- Corm dry weight (g).

- Corm circumference $(\mathrm{cm})$.

- Root length of corm (cm).

- No. of cormlets/experimental unite (cormlets yield).

- Cormlet fresh weight (g).

- Cormlet dry weight (g).

Chemical analysis of the new corms was determined in dry samples as the percentage of total carbohydrates which was determined by using colorimetric method given by Smith et al. (1956) and nitrogen (Pregel, 1945), phosphorus (Watanabe and Olsen, 1965), potassium using flame photometer (Dewis and Freitas, 1970).
The obtained data were statistically analyses using the producers outlined by Snedecor and Cochran (1980). The least significant differences (LSD) were used to compare the average of the determined parameters.

\section{RESULTS AND DISCUSSION}

Effect of growing media, organic fertilization, biostimulants and their interaction on corms yield and quality, Tables (1, 2 and 3):

Growing media strongly affected corms yield and quality in both seasons. In this connection, sand/compost medium proved its superiority for increasing corms yield (No. of corms/experimental unit), corm fresh and dry weights, corm circumference, root length of the new formed corms, as the utmost high values were obtained in both seasons. However, using sand medium in plantation occupied the second rank in improving such parameters in both seasons. In contrast, less effects were obtained in this concern due to growing plants in sand/sewage sludge $(3: 1)$ medium in the two seasons.

The aforementioned results revealed the prevalence of using sand/compost in plantation for improving corms yield, corm fresh and dry weights as well as corm circumference and root length of the new formed corms in both seasons. Such effect might be attributed to the beneficial effect of amending the organic compost into a sandy soil which improves both soil properties and plant growth. Also, decomposition of the compost allows more releasing of inorganic elements in available forms to be more easily taken by the plant roots. In addition, organic acids released during decomposition help more releasing of the nutrients from the mineral portion of the soil (Shanks and Gouin, 1985). However, the beneficial effect of sand/compost medium in improving the previous traits was confirmed by other researchers. Nasr (2000) on tuberose plant, concluded that sand/compost leaves resulted in significant increase in bulbs yield. 
Table 1. Effect of growing media, organic fertilization, biostimulants and their interaction on No. corms/experimental unite (corms yield) and corm fresh weight (g) of Gladiolus cv. Novalux during 2011/2012 and 2012/2013 seasons.

Number of corms/experimental unite (corms yield)

Corm fresh weight (g)

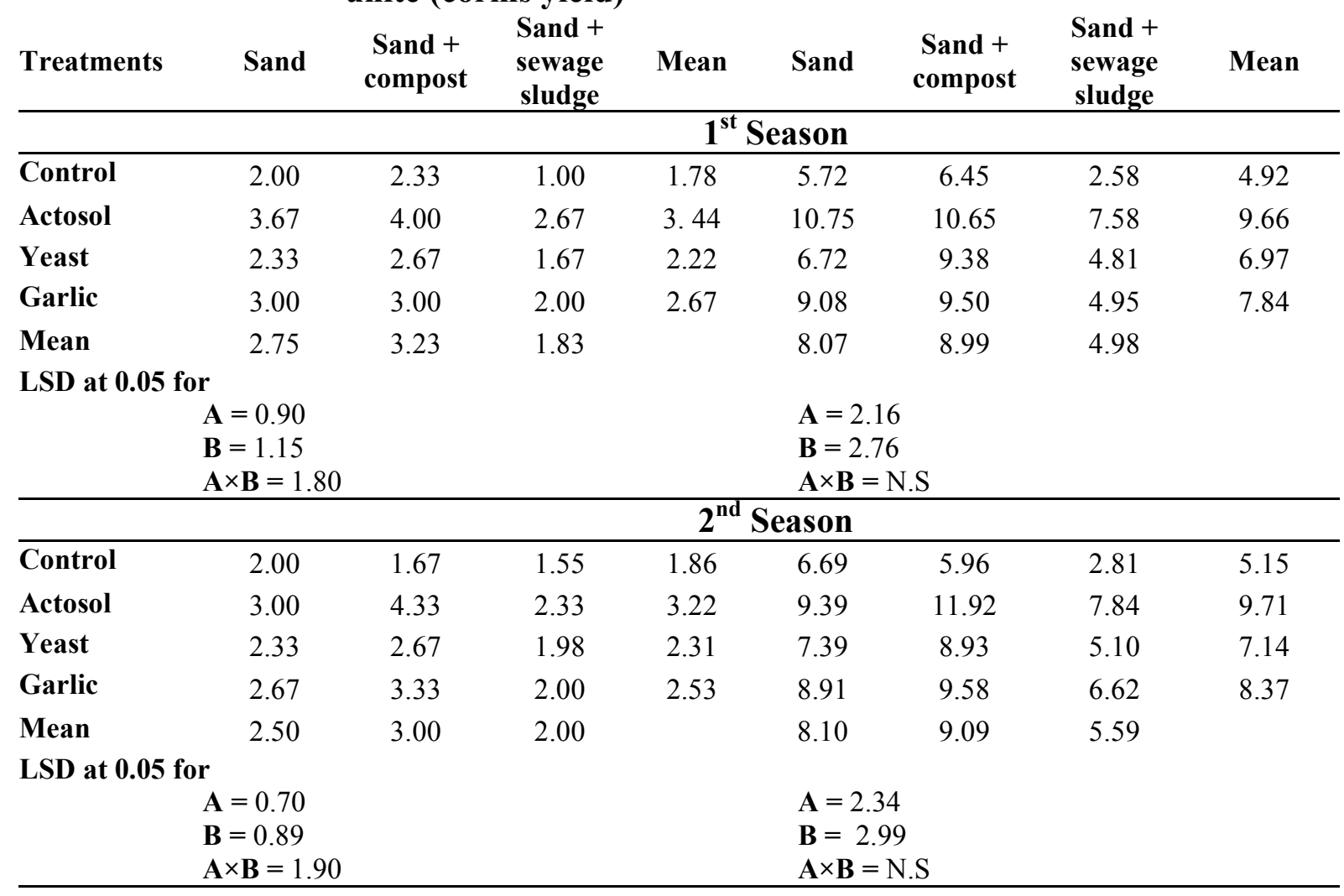

$A=$ Growing media, $B=$ Organic fertilization and biostimulants.

El-Fawakhry (2001) on Polianthes tuberosa concluded that planting the bulbs in the mixture of coarse sand + composted leaves $(1: 1 \mathrm{v} / \mathrm{v})$ showed its superiority in producing the tallest roots. Abdel- Sattar et al. (2010) on the same plant stated that planting in sand + compost mixture $(3: 1 \mathrm{v} / \mathrm{v})$ produced higher quality and quantity of bulbs.

Beneficial effects on the other side, were observed on corms yield and quality due to applying organic fertilization (actosol) and biostimulants treatments (garlic and yeast extracts) in the two seasons. In this regard, actosol treatment indicated its mastery in elevating both corms yield and quality in the two seasons, registering the utmost high values in this respect, with significant effects in all cases comparing with control. Meanwhile, applying garlic extract occupied the second rank in improving the previous traits with significant effect comparing with control in most cases. In the same time, using yeast extract slightly improved the same traits and achieved the third position in this concern.

The previous results revealed the superiority of receiving plants actosol, garlic and yeast extracts in improving corms yield, corm fresh and dry weights, corm circumference and root length of new formed corms. In this connection, many workers confirmed such results on different plant species. Referring actosol containing humic acid, Sangeetha et al. (2008) on onion mentioned that soil application of humic as $20 \mathrm{~kg} / \mathrm{ha}$ with $100 \%$ of the recommended dose of NPK fertilizers (60:60:30 kg/ha) recorded the highest number of bulbs/plant, maximum bulb girth and bulbs weight and 
Table 2. Effect of growing media, organic fertilization, biostimulants and their interaction on corm dry weight (g) and corm circumference of Gladiolus cv. Novalux during 2011/2012 and 2012/2013 seasons.

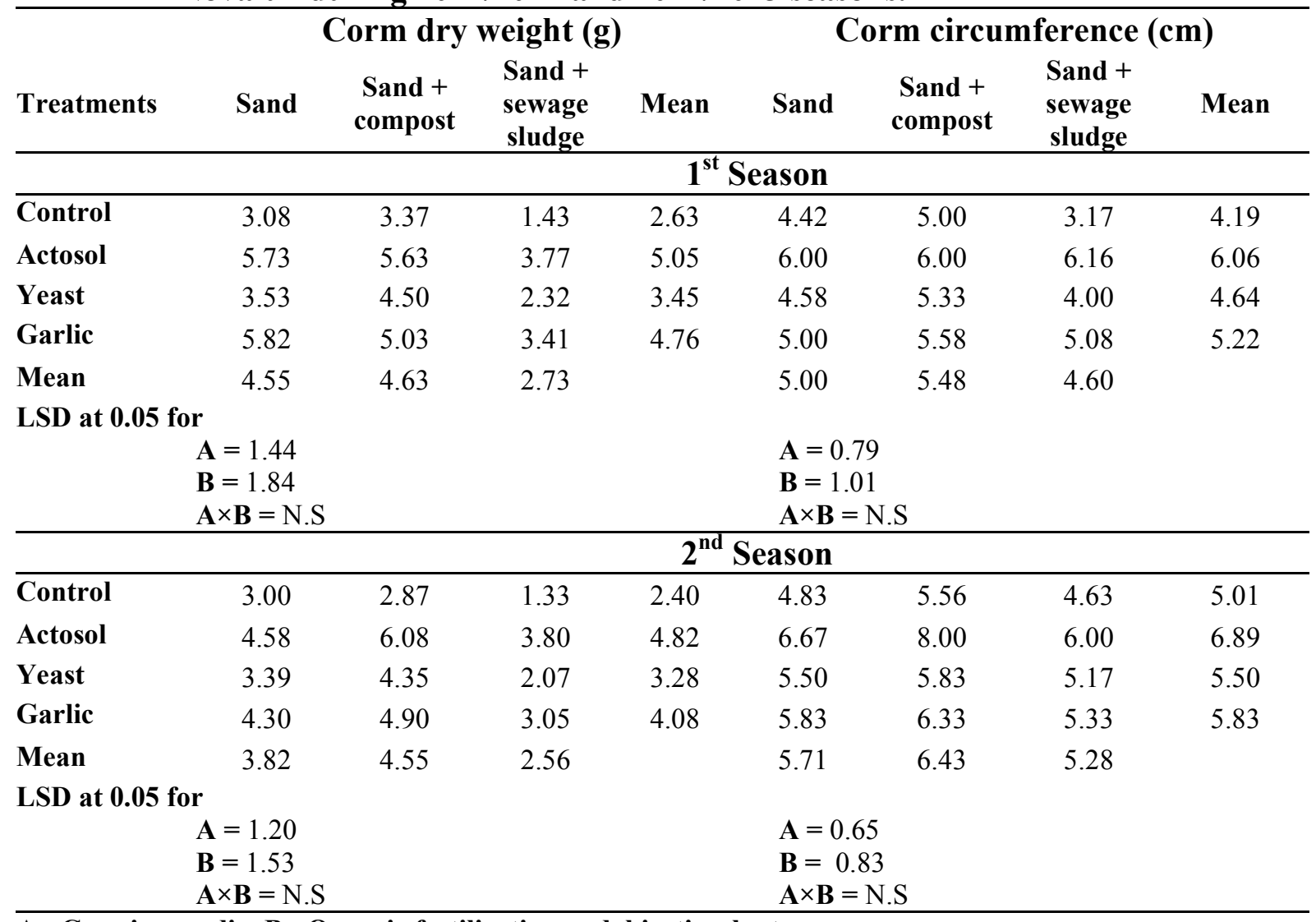

$\mathrm{A}=$ Growing media, $\mathrm{B}=$ Organic fertilization and biostimulants.

yield. Eliwa et al. (2009) on Iris tingitana cv. Wedgewood found that bulbs yield revealed an increment in response to actosol treatment at 10 or $20 \mathrm{ml} / 1$ as soil drench. Similarly, fresh weight of bulbs/plot or bulb fresh weight were increased due to actosol treatment at the rate of $2.5 \mathrm{ml} / 1$ as a foliar spray. El-sayed et al. (2010) on two gladiolus cvs. (White and Rose prosperity), concluded that soaking the corms before planting in actosol solution at the rate of 20 $\mathrm{ml} / 1$ for 0,12 and 24 hours increased new corm diameter and its fresh and dry weights.

Atowa (2012) on Freesia refracta cv. Red Lion stated that, beneficial effects were recorded due to applying actosol at $2.5 \mathrm{ml} / 1$ on corms productivity produced from cormlets. Similary, yeast extracts showed also beneficial effect on bulbs productivity. In this connection, many researchers ascertained the positive response of bulbs productivity to yeast extract. Abbass (2008) on Narcissus tazetta found that using the yeast solution led to significant increase in most studied characters.

Emam (2010) on Polianthes tuberosa concluded that highest records in fresh weight of bulbs was the outcome of applying yeast treatment at 3, 5, 7 and $9 \mathrm{ml} / 1$. Atowa (2012) on Freesia refracta cv. Red Lion stated that using yeast extract at $2.5 \mathrm{~g} / 1$ was the best for improving corms productivity with respect, to the positive influence of garlic extract on bulbs productivity, Gomma et al. (2005), found that garlic extract level $(25,50$ and $100 \%)$ as a foliar spray significantly increased bulbs yield of Narcissus tazetta cv. Geranium plant. Emam (2010) on Polianthes tuberosa, concluded that garlic extract at the lowest level $(1 \mathrm{ml} / \mathrm{l})$ increased clump fresh weight, whereas at 5 $\mathrm{ml} / \mathrm{l}$ raised clump dry weight, number of bulbs/ plant (bulbs yield).

The previous results indicated also the positive response of root length to the 
Table 3. Effect of growing media, organic fertilization, biostimulants and their interaction on root length of corm $(\mathrm{cm})$ and No. of cormlets/experimental unite (cormlets yield) of Gladiolus cv. Novalux during 2011/2012 and 2012/2013 seasons.

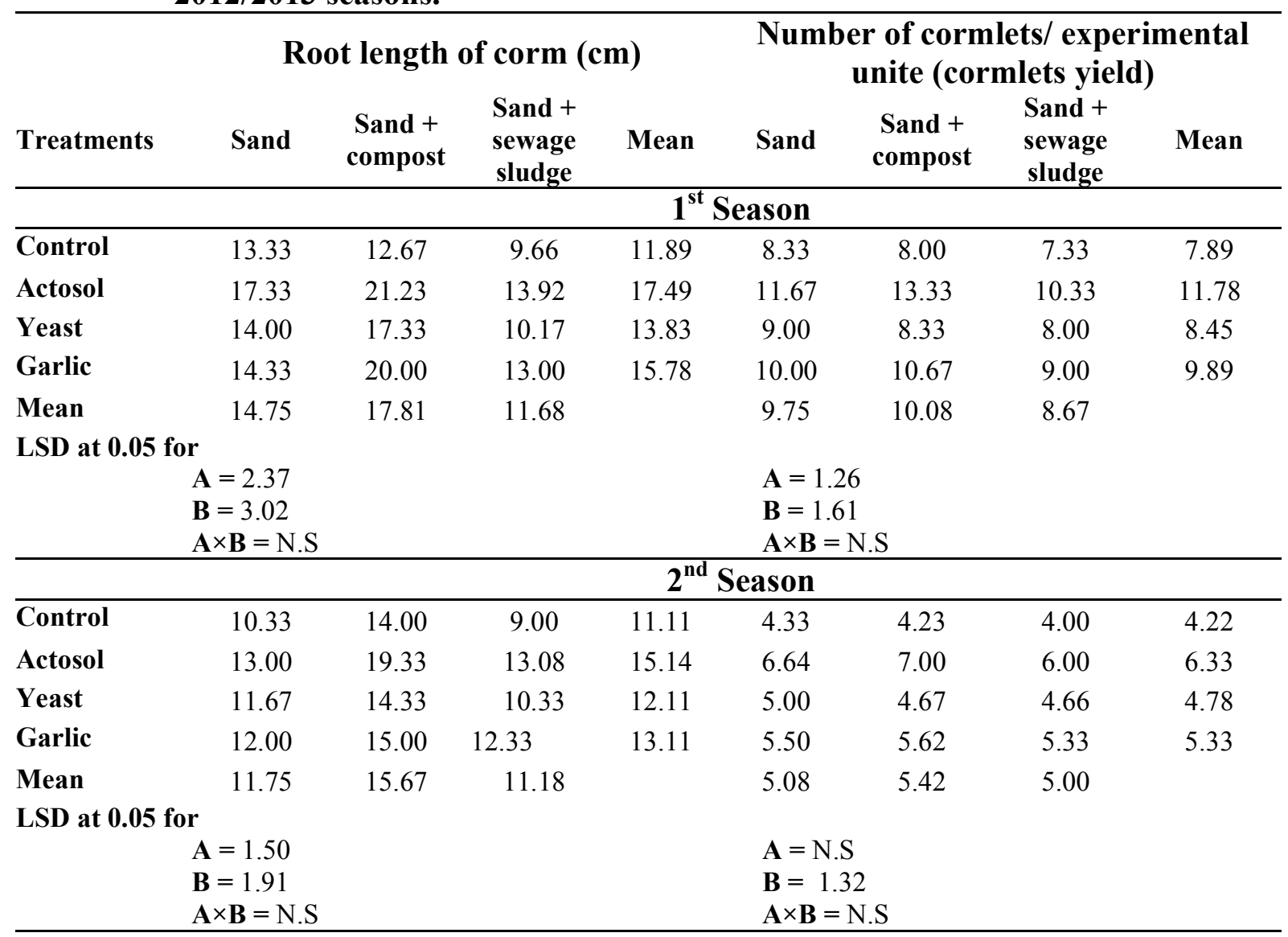

$\mathrm{A}=$ Growing media, $\mathrm{B}=$ Organic fertilization and biostimulants.

biostimulants (yeast and garlic extracts) in the two seasons. In this connection, many researchers ascertained such effect. ElDesouky et al. (1988) soaked squash (Cucurbita pepo L.) seeds in garlic extract at $50-500 \mathrm{ml} / 1$ and found that all treatments significantly increased size of root system. Abdel-Wahed et al. (2006) reported that applying yeast at $4 \mathrm{~g} / 1$ thrice to Euonymus japonicas plants led to an increment in root length. Saadawy et al. (2009) on Brassaia actinophylla reported that applying garlic extract gave rise to the highest values of all root characters studied. Also, plants treated with yeast extract had the highest values of root length.

However, the beneficial effect of yeast extract in improving corms productivity might be attributed to it contains of cytokinins which effectively promot plant growth. Moreover, the positive effects of such extract can be also attributed to its high nutrient contents, high protein, large amount of vitamin B (Ahmed, 2002). In addition both garlic and yeast extracts increased the levels of endogenous auxin, gibberellins and cytokinins (Wanas et al., 1998).

Referring, the interaction, data exhibited in Table (1) indicate the prevalence of growing plants in sand (compost medium with treating plants with actosol treatment in raising corms yield (No. of corms/experimental unite), with significant effect in both seasons. Meanwhile, the other parameters were not significantly affected by the interaction between growing media, organic fertilization or biostimulants. 
Effect of growing media, organic fertilization and biostimulant on cormlets yield and quality (Tables 3 and 4):

As mentioned above of the superiority of growing plants in sand/ compost medium for improving corms yield and quality, the same trend was also observed on cormlets yield and quality in both seasons. Meanwhile, sand medium occupied the second rank for such effect. In contrast, least scores were obtained due to using sand/sewage sludge medium in plantation.

The previous results showed the superiority of using sand/compost medium in plantation for improving cormlets yield and quality. In this connection, many workers confirmed such result on many plant species. Nasr (2000) on tuberose plant, concluded that sand/composted leaves medium resulted in significant increase in fresh and dry weights of produced bulblets. Abdel- Sattar et al. (2010) on the same plant stated that planting in sand + compost mixture $(3: 1 \mathrm{v} / \mathrm{v})$ produced higher quality and quantity of bulblets.

With regard to the effect of organic fertilization and biostimulants, data exhibited in Tables ( 3 and 4 ) indicate the superiority of treating plants with actosol for increasing cormlets yield (No. of cormlets) experimental unite, with significant effect comparing with control in both seasons. Meanwhile, applying garlic extract occupied the second position for raising cormlets yield but with significant effect comparing with control in one season only. In the same time, yeast application recorded the least effect in improving cormlets yield, with insignificant effect comparing with control in both seasons.

Table 4. Effect of growing media, organic fertilization, biostimulants and their interaction on cormlet fresh and dry weights (g) of Gladiolus cv. Novalux during 2011/2012 and 2012/2013 seasons.

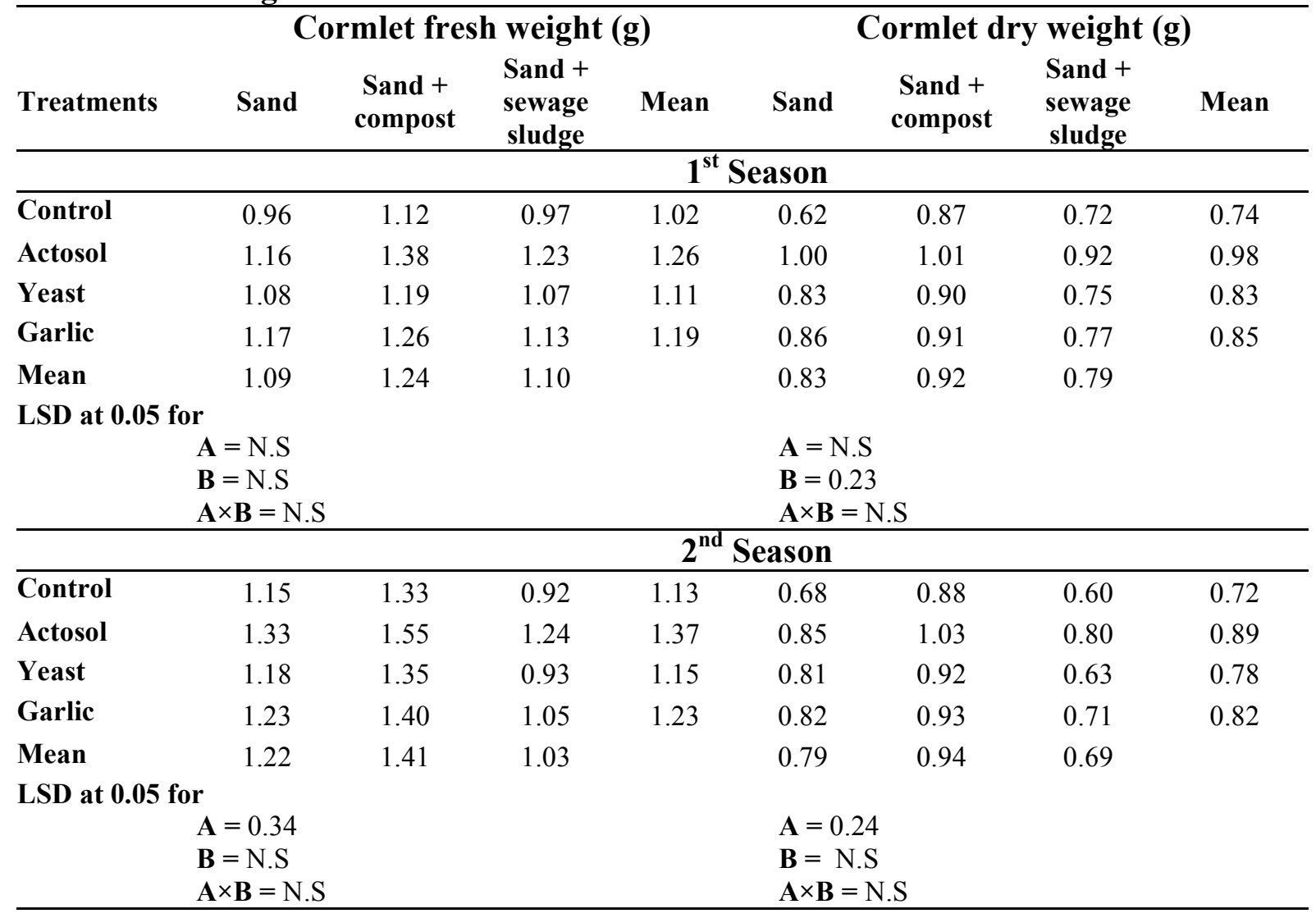

$A=$ Growing media, $B=$ Organic fertilization and biostimulants. 
In addition, either organic fertilization (actosol) or biostimulants (garlic and yeast) slightly improved cormlet fresh and dry weights, with insignificant effects in most cases.

The aforementioned results, showed the improvement of cormlets yield due to applying actosol, garlic and yeast extracts with the superiority of actosol in this concern in both seasons. However, this result is in agreement with many scientists on different bulb species. Eliwa et al. (2009) on Iris tingitana cv. Wedgewood concluded that applying actosol at $10 \mathrm{ml} / 1$ as soil drench revealed its superiority for increasing bulblets yield. El-sayed et al. (2010) on two gladiolus cvs. (White and Rose prosperity), concluded that soaking the corms before planting in actosol solution at the rate of 20 $\mathrm{ml} / 1$ for 0,12 and 24 hours increased number of cormlets/plant in both cultivars with prolonging soaking period in actosol solution. Atowa (2012) on Freesia refracta cv. Red Lion stated that, beneficial effects were recorded due to applying actosol at 2.5 $\mathrm{ml} / 1$ on cormlets productivity produced from cormlets. The favourable effect of yeast extract, on cormlets yield was also indicated by Atowa (2012) on Freesia refracta cv. Red Lion concluded that using yeast extract at 2.5 $\mathrm{g} / \mathrm{l}$ was the best for improving cormlets productivity. Concerning the beneficial effect of garlic extract on the same trait, Gomma et al. (2005), found that garlic extract level $(25,50$ and $100 \%)$ as a foliar spray significantly increased bulbs yield of Narcissus tazetta cv. Geranium plant. Emam (2010) on Polianthes tuberosa, concluded that garlic extract at the lowest level $(1 \mathrm{ml} / \mathrm{l})$ increased clump fresh weight, whereas at 5 $\mathrm{ml} / \mathrm{l}$ raised clump dry weight, number of bulbs/ plant (bulbs yield). Atowa (2012) on Freesia refracta cv. Red Lion mentioned that using garlic extract at $500 \mathrm{ml} / 1$ increased No. of cormlets/plot (cormlets yield).

The interaction, on the other hand, revealed insignificant effects on the same traits mentioned above in both seasons as can be seen in Tables (3 and 4).

Effect of growing media, organic fertilization, biostimulants and their interaction on chemical constituents of the new formed corms:

\section{1- N, P and $K \%$ :}

Data registered in Table (5) show the superiority of using sand/compost medium in plantation for raising $\mathrm{N}, \mathrm{P}$ and $\mathrm{K} \%$ in new formed corms. However, sand and sand/sewage sludge media achieved the second and third positions in this regard.

Slight increments were noticed on the same parameters due to using either organic fertilization (actosol) or biostimulants (garlic and yeast extracts), where actosol was the best comparing with that gained from control and other treatments used.

Table 5. Effect of growing media, organic fertilization, biostimulants and their interaction on $\mathrm{N}, \mathrm{P}$ and $\mathrm{K} \%$ in new formed corms of Gladiolus cv. Novalux during 2012/2013 season.

\begin{tabular}{|c|c|c|c|c|c|c|c|c|c|c|c|c|}
\hline \multirow[b]{2}{*}{ Treatments } & \multicolumn{4}{|c|}{ N\% } & \multicolumn{4}{|c|}{ P\% } & \multicolumn{4}{|c|}{$\mathrm{K} \%$} \\
\hline & Sand & $\underset{\text { compost }}{\text { Sand+ }}$ & $\begin{array}{l}\text { Sand+ } \\
\text { sewage } \\
\text { sludge }\end{array}$ & Mean & Sand & $\begin{array}{c}\text { Sand+ } \\
\text { Compost }\end{array}$ & $\begin{array}{c}\text { Sand+ } \\
\text { sewage } \\
\text { sludge }\end{array}$ & Mean & Sand & $\begin{array}{c}\text { Sand+ } \\
\text { compost }\end{array}$ & $\begin{array}{l}\text { Sand+ } \\
\text { sewage } \\
\text { sludge }\end{array}$ & Mean \\
\hline Control & 1.94 & 2.42 & 1.63 & 2.00 & 0.30 & 0.42 & 0.20 & 0.31 & 1.40 & 1.52 & 1.38 & 1.43 \\
\hline Actosol & 1.98 & 2.69 & 1.69 & 2.12 & 0.31 & 0.47 & 0.21 & 0.33 & 1.50 & 1.66 & 1.43 & 1.53 \\
\hline Yeast & 1.95 & 2.42 & 1.64 & 2.00 & 0.30 & 0.44 & 0.20 & 0.31 & 1.44 & 1.54 & 1.39 & 1.46 \\
\hline Garlic & 1.96 & 2.52 & 1.66 & 2.05 & 0.30 & 0.45 & 0.21 & 0.32 & 1.45 & 1.56 & 1.405 & 1.47 \\
\hline Mean & 1.96 & 2.51 & 1.65 & & 0.30 & 0.44 & 0.20 & & 1.45 & 1.57 & 1.40 & \\
\hline
\end{tabular}


The interactions, on the other side, indicated the prevalence of growing cormlets in sand/compost medium with treating plants by actosol in increasing $\mathrm{N}, \mathrm{P}$ and $\mathrm{K} \%$ in the new formed corms.

\section{2- Total carbohydrates\%:}

Obviously, data outlined in Table (6), indicate the superiority of growing cormlets in sand/compost medium for raising total carbohydrates $\%$ in new formed corms. However, sand and sand/sewage sludge media achieved the second and third positions in this regard. Applying either organic fertilization (actosol) or biostimulants (garlic and yeast extracts) revealed slight increments on total carbohydrates $\%$ in new formed corms comparing with that obtained from control plants where actosol treatment was the best in this respect.

The interactions, on the other side, indicated the prevalence of applying actosol treatments for plants grown in sand/compost medium in elevating total carbohydrates $\%$ in new formed corms.

The previous results show the beneficial effect of sand/compost medium in improving chemical constituents of the produced corms. This result is conformity with that obtained by El-Fawakhry (2001) on Polianthes tuberosa. He reported that the mixture of coarse sand + fine sand + compost leaves $(1: 1: 1 \mathrm{v} / \mathrm{v} / \mathrm{v})$ gave the best characters for chemical composition of the produced bulbs. concluded that sand/composted leaves gave the highest $\mathrm{N}$ and $\mathrm{P}$ contents of the produced bulbs.

The beneficial effect of organic fertilization (actosol) and biostimulants (garlic and yeast) on chemical constituents of ornamental bulbs was also confirmed by a lot of scientists on different bulb species. Eliwa et al. (2009) on Iris tingitana cv. Wedgewood stated that total carbohydrates in leaves increased due to actosol treatment at $5 \mathrm{ml} / 1$ as foliar spray + actosol at $20 \mathrm{ml}$ as soil drench + EM 5\%. Also, great effect was detected on $\mathrm{N}$ and $\mathrm{K} \%$ in leaves as a result of applying actosol at $2.5 \mathrm{ml} / 1$ as foliar spray, whereas $\mathrm{P} \%$ showed a clear increment resulting from the combination of EM 5\% and either actosol at 10 or $20 \mathrm{ml} / 1$ as soil drench. Atowa (2012) on Freesia refracta $\mathrm{cv}$. Red Lion concluded that, beneficial effects were recorded due to applying actosol at $2.5 \mathrm{ml} / 1$ in elevating total carbohydrates in leaves and $\mathrm{P} \%$ in new corms. Similarly, yeast extract revealed also beneficial effects on chemical constituents of ornamental bulbs. Abbass (2008) on Narcissus tazetta found that using the yeast solution led to significant increase in $\mathrm{N}$ and $\mathrm{P}$ content in the leaf and bulb. Atowa (2012) on Freesia refracta $\mathrm{cv}$. Red Lion stated that using yeast extract at $2.5 \mathrm{~g} / \mathrm{l}$ increased $\mathrm{N}, \mathrm{P}$ and $\mathrm{K}$ contents in the leaves. Meanwhile, $\mathrm{N}$ and $\mathrm{P} \%$ content in the new formed corms was also increased as a result of using the same yeast level $(2.5 \mathrm{~g} / 1)$. Also, Nasr (2000) on the same plant

Table 6. Effect of growing media, organic fertilization, biostimulants and their interaction on total carbohydrates \% in new formed corms of Gladiolus cv. Novalux during 2012/2013 season.

\section{Total carbohydrates}

\begin{tabular}{lcccc} 
Treatments & Sand & $\begin{array}{c}\text { Sand+ } \\
\text { compost }\end{array}$ & $\begin{array}{c}\text { Sand+ } \\
\text { sewage sludge }\end{array}$ & Mean \\
\hline Control & 17.85 & 25.35 & 15.61 & 19.60 \\
Actosol & 18.60 & 26.50 & 15.90 & 20.33 \\
Yeast & 18.25 & 26.02 & 15.75 & 20.01 \\
Garlic & 18.30 & 26.05 & 15.78 & 20.04 \\
Mean & 18.25 & 25.98 & 15.76 & \\
\hline
\end{tabular}


Concerning, the favorable effect of garlic extract on chemical constituents the previous author recorded that using garlic extract at $250 \mathrm{ml} / 1$ was the best for raising total carbohydrates content in leaves. Meanwhile, using garlic extract at 250 and $500 \mathrm{ml} / 1$ showed a favourable effect on $\mathrm{N}$ and $\mathrm{K} \%$ in leaves, respectively. Also, $\mathrm{K} \%$ content in the new corms was increased as a result of using garlic extract at either 250 or $500 \mathrm{ml} / \mathrm{l}$.

\section{REFERENCES}

Abbass, R.A. (2003). Response of Polianthes tuberosa, L. to sewage sludge addition to the newly reclaimed soils. Alex. Sci. Exch. J., 24(3):283-297.

Abbass, R.A. (2008). Response of Narcissus tazetta $\mathrm{L}$. to soil type, sea water irrigation and yeast treatment. Proc. Fourth Conf. of Sustain Develop., Fac. Agric. Fayoum Univ., 139-162.

Abdel-Sattar, M.; Allam, Samira S. and Nabih, A. (2010). Response of Polianthes tuberosa, L. plant to different growing media and $\mathrm{GA}_{3}$. Egypt. J. Biotechnol., 35: 149-171.

Abdel-Wahed, S.M.K.; Labib, Naglaa Y. and Rezkalla, B.B. (2006). Effect of active dry yeast and chemical fertilization on vegetative growth and main constituents of Euonymus japonicus Thunb plant. Fayoum J. Agric. Res. Dev., 20(1):136147.

Abou-Hadied, A.F.; El-Shinawy, M.Z. and Omer, E.A. (1998). Cultivation of garlic in nutrient film technique (NFT). Egypt. J. Hort., 25:271-280.

Ahmed, A.A. (2002). Study on the effect of addition methods and concentrations of active dry yeast on the growth and chemical composition of Leucaena leucocephola. Proc. Minia $1^{\text {st }}$ Conf. Agric. Environ, Sci., 23-28 March 2002,Minia Univ., Egypt., 33-43.

Askar, F.A. (1988). Suitability of soil conditioners for desert and cultivated soil in Egypt. Inter. Synp. Soil conditioners, Egypt:133-142.

Atowa, D.I. (2012). Effect of Growing Media, Organic and Biofertilizers on Growth and Flowering of Fressia refracta cv. Red Lion. M.Sc. Thesis, Fac. Agric. Cairo Univ., Egypt.

Bailey, L.H. (1971). Manual of Cultivated Plants. The Macmillan Company 866 Third Avenue New York N.Y. 10022 Collier- Macmillan canda Ltd. Toronto Ontario.

Dewis, J. and Freitas, F. (1970). Physical and chemical methods of soil and water analysis. Food and Agric. Organization of the United Nations, Soil Bulletin No. (10):275.

Duke, James, A. (1992). Handbook of Photochemical Constituents of Gars, Herbs and Other Economic Plants. Boca Raton., (F.L.) CRC Press. Inc. (1519) No.137.

El-Desouky, S.A; Wanas, L.A. and Kheder Z.M. (1988). Utilization of some natural plant extracts (garlic and yeast) as seedssoaking materials to squash (Cucurbita pepo L.). I. Effect on growth, sex expression and fruit yield and quality. Annals Agric. Sci. Moshtohor, 36(2): 839-854.

El-Fawakhry, F.M. (2001). Studies on Some Factors Affecting Growth, Flowering and Bulb Productivity of Polianthes tuberosa, L. Plant Ph.D. Thesis, Fac. Agric., Kafr El-Sheikh, Tanta Univ. Egypt., p. 132.

Eliwa, N.Y.; Rezk Alla, B.B.; El- Shamy, M. A. (2009). Effect of organic and biofertilizer treatments on growth, flowering, bulb production and chemical constituents of Iris tingitana cv. Wedgewood plants. J. Biol. Chem. Environ. Sci., Vol. 4(2):441- 461.

El-Sayed, A.; El-Hanafy H. Safia; Nabih, A. and Atowa, D.I. (2012). Raising Freesia refracata cv. Red Lion corms from cormlets in response to different growing 


\section{Reem M. Saeed et al.}

media and actosol levels. Journal of Horticultural Science \& Ornamental Plants, 4(1):89-97.

El-Sayed, B.A.; Moniem, A.M. and Shahin S.M. (2010). Response of Gladiolus sp. cv. White and Rose Properity plants to some fertilization treatments. J. Biol. Chem. Environ. Sci., 9(2):205- 222.

El-Seginy, Amal M. (2006). Effect of the organic fertilizer "Actosol" and "EM" biostimulant on vegetative growth and leaf chemical composition of young pear and apricot trees grown in calcareous soils. J. Agric. Sci. Mansoura Univ., 31(5):3147- 3158.

Emam, O.N.K. (2010). Effect of Treating Tuberose Plants (Polianthes tuberosa L.) With Some Organic Extracts to Improve Growth and Flowering. Ph.D. Thesis, Fac. Agric., Ain Shams Univ., Egypt.

Gomma, S.A.; Rezk Allah, B.B. and Labib, N.Y. (2005). Effect of spraying garlic extraction, gibberellic acid and potassium fertilizer on vegetative growth, flowering and bulb productivity of Narcissus tazetta L. cv. Geranium. Egypt. J. Appl. Sci., 20(5A):304-317.

Higa, T. and Widdana, G.N. (1991). Change in the soil microflora induced by effective micro organisms. P:153- 162. In J. F. Parr, S. B. Homick and C. E. Whitman (ed) proceedings of the first international Conference of Kyusei Natur Farming U. S. Department of Strkinson apple variety. China Fruits., (4):20- 21.

John, S. H. and David, A. W. (2000). Soil Conditioner. North Central Regional Extension Publication, 295.

Watanabe, F.S. and Olsen, S.R. (1965). Test of an ascorbic acid method for determining phosphorus in water and $\mathrm{NaHCO}_{3}$ extracts from soil. Soil Sci. Soc. Amer. Proc., 29:677-678.

Nady, D.M. and Hassanein M.M. (2004). Response of Dahlia pinnata, growing in sandy soil to organic and NPK fertilization treatments. Proc.
International Conference on Microbiology and Biotechnology in Favour of Man and Environment in Africa and Arab Region, 273-293.

Nasr, A.M. (2000). Effect of Some Factors on Growth, Flowering and Chemical Composition of Polianthes tuberosa, L. Plant. Ph.D. Thesis, Fac. Agric., Cairo Univ., Egypt, p. 155.

Petrovic, P.; Vitorovic, D. and Jablinovic, M. (1982). Investigation of biological effects of humic acids. Acta Biol. Meded Exp., (7):21- 25 .

Pregel, F. (1945). Quantitative Organic Micro-Analysis. $4^{\text {th }} \mathrm{Ed}$, J. and A. Churchill, Ltd. London, pp. 203-209.

Saadawy, F.M.; Rezk Allah, B.B. and Saleh Samira, A. (2009). Effect of some natural extracts on growth and development of some economically important ornamental plants. J. Agric. Res., Kafer El-Sheikh Univ., 35(2):729-757.

Sangeetha, M.; Singaram, P.; Gandhi, M. S. and Paramasivam, P. (2008). Quality characterictics of onion as influenced by lignite humic acid and inorganic fertilizers. Research on Crops, 9(1):106109.

Shanks, J. and Gouin, I. (1985). Using compost in the root medium for roses. Biocycle, 25:29- 31 .

Skoog, F. and Mitler, G.B. (1957). Biological Action of Growth Substances. Cambridge Univ. Press. Uk.

Smith, E.; Gilles, M.A.; Hamilton, D.K. and Gedees, P.A. (1956). Colorimetric method for determination of sugars and related substances Anal. Chem., 28:350.

Snedecor, G.W. and Cochran, W.G. (1980). Statistical Methods, $6^{\text {th }}$ ed., Iowa State Univ. Press, Ames, Iowa, U.S.A.

Stevenson, I.J. (1994). Humus chemistry: Genesis, Composition, Reaction $2^{\text {nd }}$ ed. John Wiley and Sons, Inc. New York. 
Wanas, A.L.A.; El-Desouky, S.A. and Kheder, Z.M.A. (1998). Utilization of some natural plant extracts (garlic \& yeast) as seed-soaked materials to squash
(Cucurbita pepo L.) II. Effect on the histological features and the endogenous hormones. Annals of Agricultural Science, Moshtohor, 36 (2):855-878.

\section{تأثير بيئات النمو، التسميد العضوي والمحفزات الحيوية على إنتاج كورمات الجلاديولس

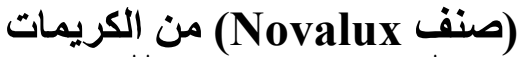

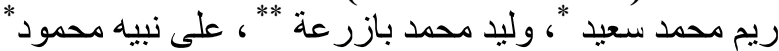

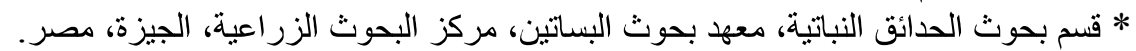 \\ ** قسم بحوث الزينة وتنسيق الحدائق، معهد بحوث البساتين، مركز البحوث الزئن الزراعية، الجيزة، مصر.}

في محاولة لحل مشكلة من أهم المشاكل التي تواجه إنتاج الجلاديولس في مصر ألا وهي التدهور في إنتاج كورمات

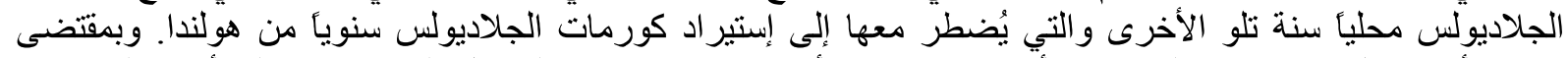

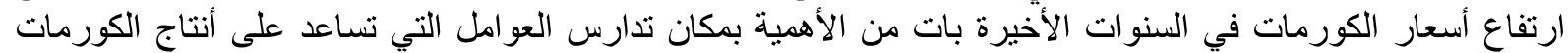

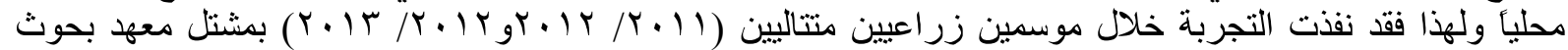

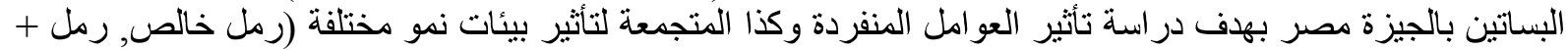

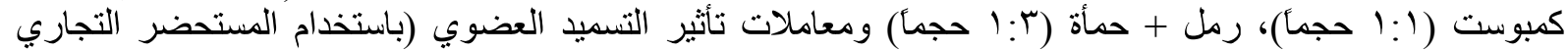

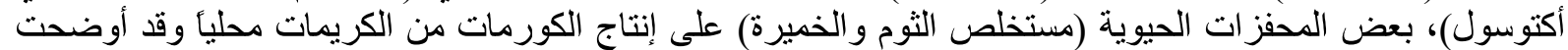

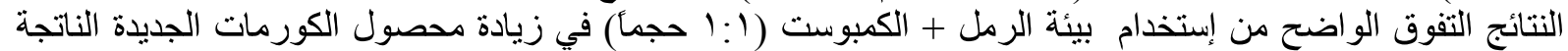

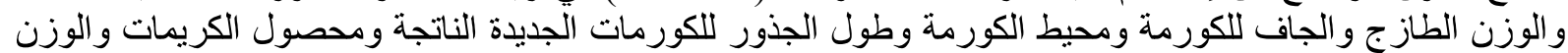

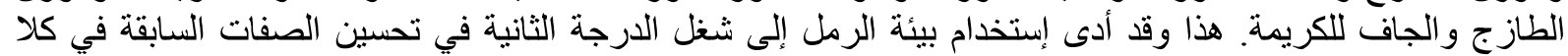

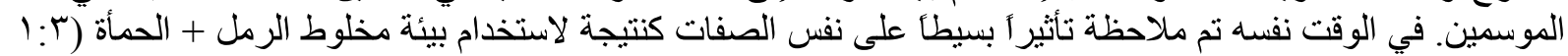

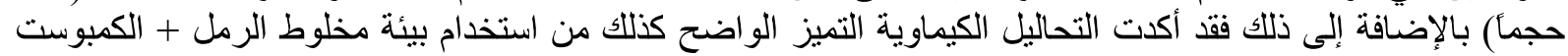

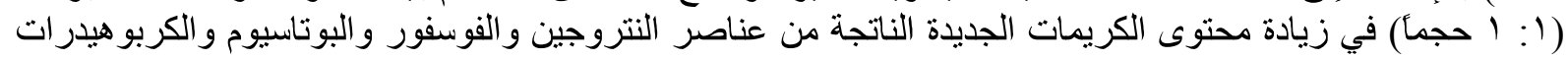
الكلية.

ومن جهة أخرى أكدت النتائج التفوق الواضح من استخدام الأكتوسول في زيادة محصول الكورمات الناتجة في كلا

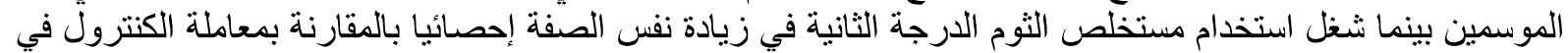
معظم الحالات هذا وقد اظهر استخدام مستخلص الخميرة تأثير آ بسيطأ بالنسبة لنفس الصفة مع شغله الدرجة الثة الثانية في هذا

أوضحت النتائج كذلك التفوق الواضح من استخدام الأكتوسول في معاملة النباتات في زيادة محصول الكريمات بينما

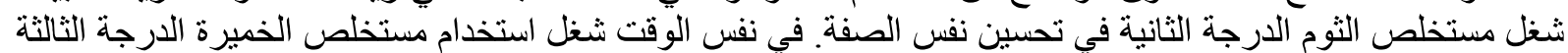

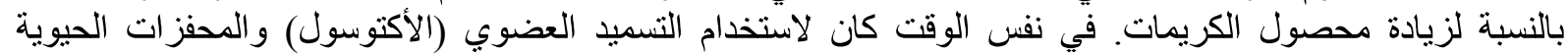

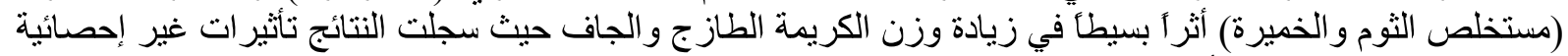

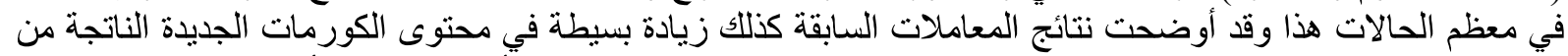

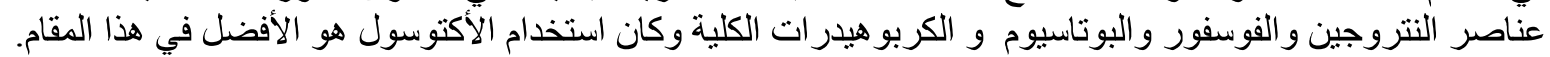

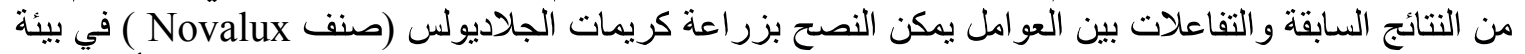

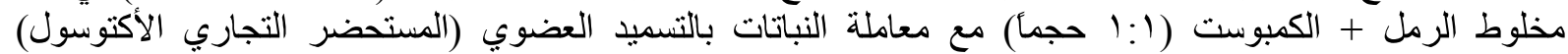
للحصول على أكبر محصول من الكورمات الجديدة ذات صفات عالية الجودة. 